\title{
Citriculture and Climate Change
}

\author{
Waleed Fouad Abobatta* \\ Citrus Research Department, Horticulture Research Institute, Egypt
}

ISSN: 2637-7659

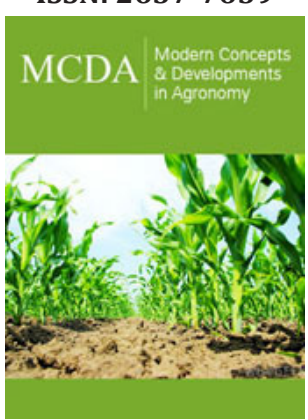

*Corresponding author: Waleed Fouad Abobatta, Citrus Research Department, Horticulture Research Institute, Agriculture research center, Egypt

Submission: 眥June 08, 2020

Published: 侮June 11, 2020

Volume 6 - Issue 3

How to cite this article: Waleed Fouad Abobatta. Citriculture and Climate Change. Mod Concep Dev Agrono. 6(3). MCDA. 000639. 2020. DOI: 10.31031/MCDA.2020.06.000639

Copyright@Waleed Fouad Abobatta This article is distributed under the terms of the Creative Commons Attribution 4.0 International License, which permits unrestricted use and redistribution provided that the original author and source are credited.

\section{Background}

Citrus is an important evergreen economic tree in different regions in the world, and there is a significant relationship between its yield and climate conditions in different growth stages. In the climate change era, there is more need to understanding the impacts of climate change on citrus growth and productivity and the influence of the potential climate changes in the next decades in major citrus production regions such as the U S A, Brazil, Egypt, Spain, Australia, South Africa, Turkey, and South Asia [1]. Climate change is a major challenge to citrus production worldwide and has directly affected tree yields, consequently, reduce growers' profitability, as well as maybe changing the geographic distribution of varieties and production regions, therefore, there is requires new strategies addressing these challenges [2].

\section{Impact of climate change on citrus growth and productivity}

Citrus cultivation requires specific climate conditions including temperature, humidity, solar radiation, and light intensity, whereas yield and fruit quality are very delicate to temperature and drought, also, climate conditions affect spreading pests, disease, and weeds. Citrus originated in South East Asia and spreading to other continents, citrus adapted to grow in varied climate conditions and soil types from tropical, subtropical, temperate, and semiarid regions. Recently, the cultivated area of citrus is more than seven million hectares approximately, planted in 140 countries almost under warm temperate regions [3]. The Mediterranean climate considered the appropriate climate for citrus cultivation, whereas after global warming and nonstop changes in a climate there is a change of citrus tree behavior required altered timing of regular agricultural practices during the whole season. There are numerous species and cultivars in genus citrus, but the main cultivated species are sweet oranges (Citrus sinensis (L.) Osbeck), mandarins group (Citrus spp.), grapefruits (Citrus paradisi), lemons (Citrus limon (L.)), lime (Citrus aurantifolia) and pummelo (Citrus maxima) [4]. Under weather fluctuations, there are various elements of climate that affect negatively citrus growth and productivity including (High temperature, Heatwaves, Low temperature, Drought, Flooding, and Soil Salinity), whereas, rising temperature and drought considered the main abiotic threats of citrus cultivation) [5]. Citrus responses to the abiotic stresses related to the interaction of various factors like temperature, humidity, and tree nutritional status...etc, therefore, exposure citrus tree to combinations of abiotic stresses at the same time cause more deleterious than acting of any individual factors in citriculture in terms of yield and fruit quality, also, climate change has triggered pest's infestation, disease frequency, and water requirement and increased production cost. Rising temperature simultaneously with water shortage, affect severely on photosynthesis and increasing oxidative damage, also, combinations of environmental factors affect productivity, sustain of citrus cultivation [6]. 


\section{Negative effects of climate change on citrus production}

There are various negative effects of climate change on citrus growth and productivity, including:

1. Inhibiting tree growth.

2. Impaired metabolic processes (Reducing stomatal conductance, decrease leaf transpiration rate, and minimize net $\mathrm{CO}_{2}$ assimilation

3. Increase spreading of pests and pathogens.

4. Limitation of productivity, delaying color breaks particularly in early varieties like Hamlin sweet orange.

5. Increase the physiological disorder of fruits (e.g. Sunburn, cracking, and splitting).

\section{Adaptation strategies}

There are various factors that affect citrus trees adaptation to climate change, and for that, adapting strategies are very important for diminishing this recently emerging danger of climate change on citrus production worldwide, some of these strategies as follow:

\section{Canopy management}

2. Top netting [7].

3. Soil fertility management

4. Using water-saving strategies.
Undoubtedly climate change affects the citrus production and limiting the profitability of growers, therefore, there is more attention to understanding how potential climate change will affect the productivity of citrus globally.

\section{References}

1. Food and Agriculture Organization of the United Nations (FAO), (2015) FAOSTAT: food and agriculture organization of the United Nations Statistics division. Rome, Italy.

2. Balfagon D, Zandalinas SI, Gomez Cadenas A (2018) High temperatures change the perspective: integrating hormonal responses in citrus plants under co-occurring abiotic stress conditions. Physiologia Plantarum 165(2): 183-197.

3. United States Department of Agriculture (USDA) (2016/2017) statistics.

4. Abobatta WF (2019) Citrus Varieties in Egypt. Int Res J Applied Sci 1(1): 63-66.

5. Ahmad S, Firdous I, Jatoi GH, Rais MUN, Mohsin AQ (2017) Economic impact of climate change on the production of citrus fruit in Punjab province of the Pakistan. Sci Int (Lahore) 29(2): 413-415.

6. Abobatta WF (2020) Plant responses and tolerance to combined salt and drought stress. Salt and Drought Stress Tolerance in Plants, pp. 17-52.

7. Cronje PJR, Botes J, Prins DM, Brown R, North J, et al. (2020) The influence of $20 \%$ white shade nets on fruit quality of 'Nadorcott' mandarin. Acta Hortic 1268(36): 279-284.

For possible submissions Click below: 